\title{
The Effect of Waxing Options on Shelf Life and Postharvest Quality of "ngowe" Mango Fruits under Different Storage Conditions
}

\author{
Benson Maina $\mathbb{D}^{\mathbb{D}}{ }^{1}$ Jane Ambuko $\mathbb{D}^{1},{ }^{1}$ Margaret J. Hutchinson, ${ }^{1}$ and Willis O. Owino $\mathbb{D}^{2}$ \\ ${ }^{1}$ Department of Plant Science and Crop Protection, Faculty of Agriculture, University of Nairobi, Nairobi 29053-00625, Kenya \\ ${ }^{2}$ Department of Food Science and Technology, Faculty of Agriculture, Jomo Kenyatta University of Agriculture and Technology, \\ Nairobi 62000-00200, Kenya
}

Correspondence should be addressed to Benson Maina; mainabenson866@gmail.com

Received 15 February 2019; Revised 26 May 2019; Accepted 28 May 2019; Published 4 December 2019

Academic Editor: Ayman Suleiman

Copyright (C) 2019 Benson Maina et al. This is an open access article distributed under the Creative Commons Attribution License, which permits unrestricted use, distribution, and reproduction in any medium, provided the original work is properly cited.

\begin{abstract}
Mango is an economically important fruit crop but with a very short shelf life of about 4-9 days in ambient and between 2 and 3 weeks in cold storage. Extending the shelf life and marketing period of mango fruit requires application of quality preservation technologies. This study aimed at evaluating the effect of innovative waxing options on shelf life and postharvest quality of "ngowe" mango fruits stored under different storage conditions. A homogenous sample of mango fruits, variety "ngowe" harvested at mature green stage were subjected to two waxing treatments, namely Shellac or Decco wax ${ }^{\text {tru. }}$. The waxes were applied by dipping the fruits in wax for five seconds followed by air drying. The waxed fruits were then packed in carton boxes and stored either at ambient room temperature $\left(25^{\circ} \mathrm{C}\right)$ or cold room $\left(12^{\circ} \mathrm{C}\right)$. Random samples of three fruits from each treatment and storage conditions were taken for measurement of attributes associated with ripening after every 3 and 7 days for ambient and cold storage, respectively. These included cumulative weight loss, respiration, peel firmness, total soluble solids (TSS), total titratable acidity (TTA) and beta carotene content. Results from the study showed that waxing with either Shellac or Decco wax was effective in prolonging shelf life of "ngowe" mango fruits by 3 and 6 days in ambient and cold storage respectively. Untreated fruits in ambient storage lost 5.3\% of the initial weight by day 7 compared to an average of $4.5 \%$ for the waxed fruit (day 10). Waxed fruits in ambient had low $\mathrm{CO}_{2}$ concentration $(59.53 \mathrm{ml} / \mathrm{kg} \mathrm{hr})$ compared to a high $(88.11 \mathrm{ml} / \mathrm{kg} \mathrm{hr}) \mathrm{CO}_{2}$ concentration for the untreated fruits. Similarly, other ripening related changes including brix, color, and firmness were significantly slowed down by waxing, especially under cold storage. Findings from this study show the effectiveness of waxing in delaying mango fruit ripening. Waxing can therefore be used to extend the shelf life and marketing period for mango fruit.
\end{abstract}

\section{Introduction}

Mango (Mangifera indica L.) fruit is consumed globally due to its delicious taste and nutritional value (carotenoids, ascorbic acids, quercetin and mangiferin) [1]. However, mango has a very short shelf life depending on harvest maturity and storage conditions [2-4]. Its perishability is further exacerbated by poor postharvest handling operations (inducing damage that leads to rots) and limited postharvest technologies to delay ripening. Handling operations during harvesting and packing of fruits, causes breaks on the skin and loss of cuticle thus predisposing the fruits to quick deterioration due to high water loss, high respiration, and pathological attack $[5,6]$. Water loss from mango fruits leads to loss in firmness, loss in gloss value due to shrinking, and loss of nutritional value such as vitamin C. Others include loss of salable weight and discount selling due to poor looking fruits. In order to extend shelf life and preserve postharvest quality of mango fruits, various postharvest technologies such as Controlled Atmosphere Storage (CAS) [7], modified atmosphere packaging [8], evaporative cooling [8], and cold storage [9], among others have been found to be beneficial. However, some of these postharvest technologies have been reported to have negative effects on mangoes such as chilling injury, gas injury [10], fear of environmental pollution, and limited accessibility by small holder farmers many of whom are in developing countries. These challenges have therefore necessitated research on alternative postharvest technologies which would be affordable, accessible, and easy to use. Recently, there 
has been a great interest in biopolymer based coatings due to their environmental friendly nature and with a potential to be used in food industry. Such include the use of waxes which has been shown to be a simple and versatile postharvest technology, reported to have beneficial effects on postharvest handling of other perishable commodities including coating citrus and apples with carnauba and shellac, and apricots with sucrose fatty acid esters [11, 12], among others. However, if the wax composite is not well prepared, it can be detrimental as it can completely block fruit respiration leading to a quick deterioration [13].

The function of waxing to extend shelf life and maintain postharvest quality is based on the modification of the internal gas and moisture composition of the produce. Waxing can be applied by either spraying or dipping. Upon drying, the coating forms a thin film around the surface of produce which then creates a modified internal environment [14]. The coating applied limits the amount of water leaving the produce through transpiration by reducing the number and sizes of the lenticels, thus leading to a water saturated internal environment and also regulates gaseous exchange on the surface of the fruit leading to a high $\mathrm{CO}_{2}$ and low $\mathrm{O}_{2}$ levels inside the fruit [15]. The low oxygen conditions created by waxing affects physiological processes such as respiration and enzyme mediated processes such as the ethylene biosynthesis pathway. The low $\mathrm{O}_{2}$ condition has been reported to limit activities of 1-Aminocyclopropene-1-Carboxylic acid (ACC) oxidase [16] the enzyme that catalyzes the conversion of ACC to ethylene. Low activities of the enzymes involved in the degradation of chlorophyll and cell wall degradation have also been reported to occur with low $\mathrm{O}_{2}$ conditions $[17,18]$.

In order to realize the beneficial effect of waxing, it is important to match the commodity's characteristics to those of the waxing material. Furthermore, the effectiveness of the waxing material could be improved by addition of active ingredients such as fungicides which help to deter fungal attack [19, 20]. The objective of this study was to investigate the effect of two types of waxes (Decco and Shellac wax) on postharvest quality preservation and shelf life extension of ngowe mango, a popular mango variety in Kenya.

\section{Materials and Methods}

2.1. Materials. "Ngowe" mango fruits at mature green stage (color around seed turning cream/yellow) were harvested from commercial farms in Machakos County, Kenya. The fruits were packed in plastic crates lined with wet paper for cushioning and transported to the postharvest laboratory in the University of Nairobi.

Decco wax, Decco clear (food brush sanitizer) and Decco spark (disinfectant) were obtained from United phosphorus Limited, while shellac wax was obtained in flakes form from a commercial trader and the flakes dissolved in $0.01 \mathrm{~N}$ sodium hydroxide to make a concentration of $5 \%, w / w$.

\subsection{Method}

2.2.1. Pre-Treatment. In the laboratory, the fruits were sorted for uniformity and then washed with disinfectant water containing calcium chloride $(0.18 \mathrm{~g} / \mathrm{L})$. A fine brush dipped in Decco clear solution ( $50 \%$ diluted in water) was used to brush dirt on the fruits, after which they were dipped in hot water $\left(45-55^{\circ} \mathrm{C}\right)$ for 10 seconds, removed and placed on wire shelves for air drying.

2.2.2. Treatment. The fruits were then batched into three groups for different treatments which included untreated, $5 \%$ Shellac wax and Decco Wax. Wax was applied by dipping the fruits in bowls containing the different waxes and placed on wire shelves for drying. After drying, the fruits were packed in open carton boxes and stored at ambient room temperature $\left(25^{\circ} \mathrm{C}\right)$ or under cold storage $\left(12^{\circ} \mathrm{C}\right)$. Three fruits from each treatment and storage conditions were randomly sampled after every 3 and 7 days in ambient and cold storage respectively for analysis of attributes associated with ripening and quality. These included weight loss, firmness, respiration, beta carotene, total soluble solids and total titratable acidity. Three replicates of sixty fruits were used per treatment in all experiments. Completely Randomized Design with factorial arrangement was used as the study design.

Treatment protocol was designed by United Phosphorous Limited.

\subsection{Assessment of Shelf Life and Postharvest Quality}

2.3.1. Cumulative Weight Loss. Mass loss for 5 fruits was taken and recorded using a digital balance (Model Libror AEG-220, Shimadzu Corp. Kyoto, Japan). The initial weight (W1) of each fruit (marked) at day 0 and the new weight of the same (W2) was taken for the subsequent days. The formula;

$$
\text { Cumulative Weight loss } \%=\frac{(W 1-W 2)}{W 1} * 100 .
$$

2.3.2. Respiration. Mass loss for 5 individual fruits (marked at day 0) from each treatment and storage condition was taken and recorded using a digital balance (Model Libror AEG-220, Shimadzu Corp. Kyoto, Japan) each sampling day. The fruits were then separately incubated in air tight jars fitted with a $\mathrm{CO}_{2}$ gas sensor (Model CM-0187 Cozir AMB, UK) for 2 hours. Gas sample from the headspace was read by the $\mathrm{CO}_{2}$ sensor and a graph drawn from which the slope was used to calculate the amount of $\mathrm{CO}_{2}$ in $\mathrm{ml}$ per Kg Hour. The following formula was used to calculate $\mathrm{CO}_{2}$ produced:

$$
\text { Respiration }=\frac{G \times \text { Volume of vessel }}{\text { Time } \times M},
$$

where $G$-slope of the curve; $M$-mass of fruits in kilogram.

2.3.3. Peel Firmness. Five fruits randomly selected from each treatment and storage conditions were sampled and an average of two measurements of firmness along the equatorial area recorded. A penetrometer (CR_100D, Sun Scientific Co. Ltd, Japan) having a $5 \mathrm{~mm}$ probe was used to puncture the fruits and the maximum force required to puncture the fruit was recorded. Firmness was expressed as Newton (N).

2.3.4. Pulp Color. Pulp color change in the fruit was measured at 2 different spots along the equator using Minolta color difference meter (Model CR-200, Osaka, Osaka Japan) which had been calibrated on a white and black standard tile. To access the pulp, the fruit was cut open longitudinally. 
The $\mathrm{L} *, \mathrm{a} *$ and $\mathrm{b} *$ values were recorded and used to calculate the hue angle $(\mathrm{H})$ using the below formula:

Hue angle $(H)=$ Hue angle $(H 0)=\arctan \left(\frac{b}{a}\right)$ for $+a+b$ values.

2.3.5. Total Titratable Acidity. The TTA was determined by titration. Ten grams of the fruit pulp was ground and diluted with $90 \mathrm{~mL}$ of distilled water. $10 \mathrm{ml}$ of the dilute solution was obtained, mixed with 2-3 drops of phenolphthalein indicator (colorless in acid medium) for titration against $0.1 \mathrm{~N}$ sodium hydroxide with constant shaking, till the mixture showed appearance of pink color. The TTA was expressed as percentage citric acid content of the fruit juice.

$\%$ Citric acid equivalent

$$
=\frac{\text { Sample reading }(\mathrm{ml}) * \text { Dilution factor }}{\text { Sample weight }(\mathrm{mg}) * \text { Citric factor }(0.00064) * 100} .
$$

2.3.6. Total Soluble Solids. An Atago hand refractometer (Model 500, Atago, Tokyo, Japan) was used to determine the TSS levels. Fruits from each treatment were randomly picked and a blender used to macerate the pulp. The pulp was then placed on the glass prism and an average of three readings recorded.

2.3.7. Determination of $\beta$-carotene Content. The $\beta$-carotene content was determined by a modified chromatographic procedure [34]. A sample of $5 \mathrm{~g}$ was macerated in pestle and mortar. A spatula of celite was then added and extracted using $50 \mathrm{~mL}$ acetone until the residue became white. Partitioning was done using $30 \mathrm{~mL}$ of petroleum ether in a separating funnel. Distilled water $(200 \mathrm{ml})$ was then added along the walls of the funnel. The two phases were separated and the lower aqueous phase discarded. Acetone residues were removed by washing three times with distilled water without discarding the upper phase. Sodium Sulphate (anhydrous) was added to remove water and the extracts were stored in sample bottles in a dark cabinet. $\beta$-carotene content was determined using ultraviolet visible spectrophotometer (Model UV mini 1240, Kyoto Shimadzu) and absorbance read at $440 \mathrm{~nm}$. The $\beta$-carotene content was calculated using the following equation:

$$
\text { Carotenoid content }\left(\frac{\mu g}{g}\right)=\left(\frac{A \times V(\mathrm{ml}) \times 10^{4}}{1 \% / 1 \mathrm{~cm} \times P(\mathrm{~g})}\right)
$$

where $A=$ absorbance; volume = total volume of extract $(50$ or $25 \mathrm{ml}) ; \mathrm{A}^{1 \%} 1 \mathrm{~cm}=$ absorption coefficient of $\beta$-carotene in PE (2592).

\section{Results}

3.1. Cumulative Weight Loss. There was a gradual weight loss in all the fruits in the different storage conditions but the loss was significantly $(p<0.05)$ higher for the untreated fruits compared to the waxed fruits (Figures $1(\mathrm{a})$ and $1(\mathrm{~b})$ ). Fruits under cold storage had significantly $(p<0.05)$ lower weight loss compared to the ambient stored fruits each sampling day. A combination of waxing and cold storage further reduced the weight loss by almost half when compared with fruits that were waxed and stored in ambient. Under ambient storage conditions, untreated fruits lost $5.3 \%$ of the initial weight (day 7) compared to an average of $4.5 \%$ for the treated fruits 3 days later (Figure 1(a)). For the cold stored fruits, untreated fruits lost $3.8 \%$ of the initial weight by end of storage period (day 22) compared to an average of $3.65 \%$ for the treated fruits 6 days later (Figure 1(b)). Decco wax performed slightly better in ambient storage conditions but there was no significant $(p<0.05)$ difference with $5 \%$ Shellac wax. Waxing mango helped to reduce weight loss in both storage conditions and it showed to be more effective when combined with cold storage conditions.

3.2. Respiration Rate. The rate of Carbon dioxide concentration is an indicator of the metabolic activity which signals on the possible shelf life of a given produce. Carbon dioxide concentration increased in all fruits as ripening progressed during the storage period (Figures 2(a) and 2(b)), but the rate was slower for the waxed fruits compared to un waxed fruits. Fruits under cold storage had significantly $(p<0.05)$ low respiration rate compared to ambient stored fruits, each sampling day. In ambient storage conditions, $\mathrm{CO}_{2}$ concentration for the untreated fruits rapidly increased to a high peak of $88.11 \mathrm{ml} / \mathrm{kghr}$ (day 7) compared to a low average peak of $59.53 \mathrm{ml} / \mathrm{kghr}$ (day 10) for the treated fruits (Figure 2(b)). Unlike the ambient stored fruits (treated and untreated) whose respiratory peak appeared on the same day (Figure 2(a)), the treated fruit's $\mathrm{CO}_{2}$ concentration peak under cold storage appeared 7 days (Figure 2(b)). The untreated respiratory level reached a high peak of $39.94 \mathrm{ml} / \mathrm{kghr}$ (day 8) and thereafter declined through out to the end of storage period compared to the waxed fruits which had a smaller average peak of $30.19 \mathrm{ml} / \mathrm{kghr}$, which occurred 7 days later and then remained fairly constant throughout the storage period (Figure 2(b)). Waxing reduced respiration rate of the mangos in both storage conditions but the effect was more in ambient stored fruits.

3.3. Changes in Peel Firmness. In both storage conditions, a general decrease in peel firmness was observed regardless of treatment, but the rate was slower for the treated fruits compared to untreated (Figures 3(a) and 3(b)). A combination of cold storage and waxing further delayed firmness loss. Under ambient storage conditions, untreated "ngowe" mango fruits' firmness decreased from an initial $105.68 \mathrm{~N}$ to $10.2 \mathrm{~N}$ by end of storage period (day 7) compared to an average of $19.13 \mathrm{~N}$ for the treated fruits which occurred 3 days later (Figure 3(a)). For the cold stored fruits, untreated fruit's firmness decreased to $14.6 \mathrm{~N}$ compared to an average of $18.77 \mathrm{~N}$ for the treated fruits which occurred 6 days later (Figure 3(b)).

3.4. Changes in Pulp Hue. A general decrease in pulp Hue angle was observed in all fruits as ripening progressed irrespective of treatment or storage conditions. Cold storage $\left(12^{\circ} \mathrm{C}\right)$ significantly $(p<0.05)$ delayed color development 


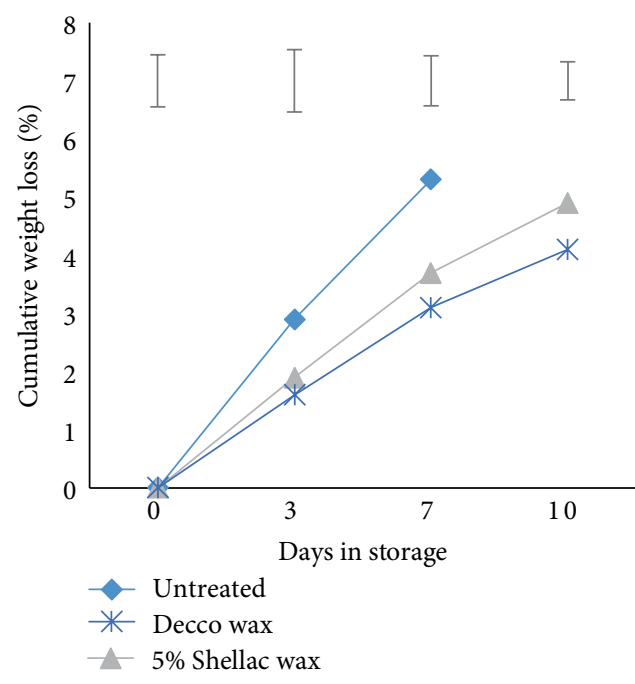

(a)

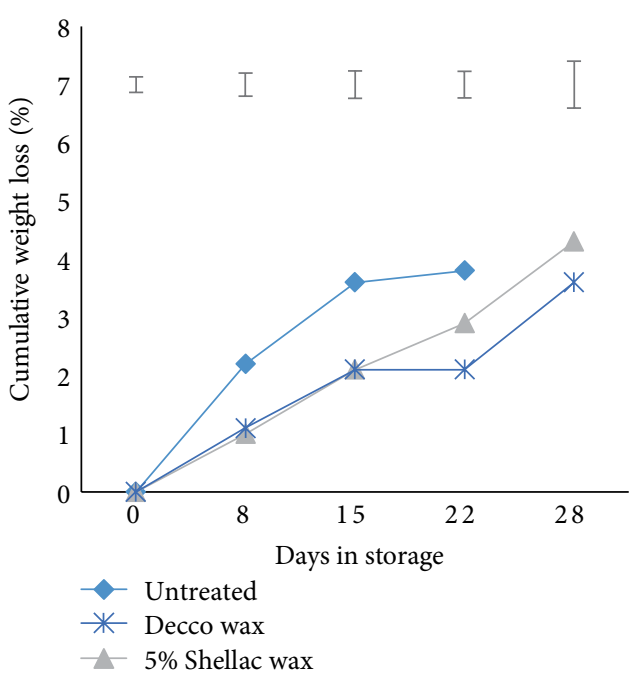

(b)

FIGURE 1: Changes in cumulative weight loss (\%) for "ngowe" mango fruits which were treated with either $5 \%$ Shellac wax or Decco wax or left Untreated (Control) and stored at ambient room temperature, $25^{\circ} \mathrm{C}$ (a) or cold room, $12^{\circ} \mathrm{C}$, (b) top bars represent least significant difference (LSD) of means $(p=0.05)$.

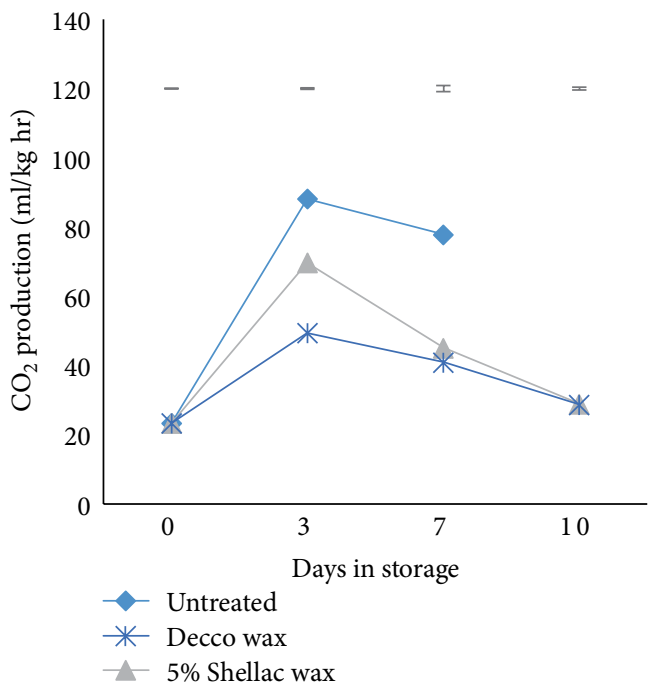

(a)

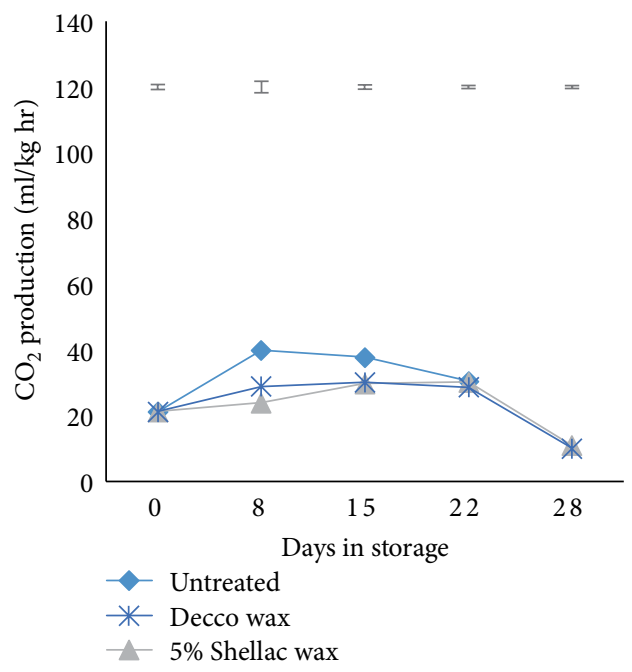

(b)

Figure 2: Changes in $\mathrm{CO}_{2}$ concentration $(\mathrm{ml} / \mathrm{kg} \mathrm{hr}$ ) for "ngowe" mango fruits which were treated with either 5\% Shellac wax, Decco wax or left Untreated (Control) and stored at ambient room temperature, $25^{\circ} \mathrm{C}$ (a) or cold room, $12^{\circ} \mathrm{C}$, (b) top bars represent least significant difference (LSD) of means $(p=0.05)$.

compared to ambient storage $\left(25^{\circ} \mathrm{C}\right)$. Waxing delayed color change in the fruits stored in cold storage (Table 1) compared to the waxed ambient stored $\left(25^{\circ} \mathrm{C}\right)$ fruits (Table 2). There was no significant $(p<0.05)$ difference between waxed and un waxed fruits in cold storage up to day 15 . The hue angle for the untreated "ngowe" mango fruits stored in ambient decreased from an initial $92.51^{\circ}$ to- $76.38^{\circ}$ compared to an average of $82.19^{\circ}$ for the treated fruits which occurred 3 days later. For the "ngowe" mango fruits in cold storage, untreated pulp hue decreased to $78.39^{\circ}$ (day 22) compared to an average of $81.71^{\circ}$ for the treated fruits which occurred 6 days later.
3.5. Total Titratable Acidity (TTA). A general decrease in TTA content was observed in all fruits as ripening progressed, but the rate was significantly $(p<0.05 \%)$ lower in cold storage compared to ambient storage (Tables 3 and 4). A combination of waxing and cold storage further delayed TTA reduction compared to ambient storage conditions. Under ambient storage conditions, untreated "ngowe" mango fruit lost $86.35 \%$ equivalent of citric acid by day 7 compared to an average of $62.78 \%$ for the treated fruits that occurred by day 10 (Table 3 ). For the cold stored "ngowe" mango, untreated fruits lost 1.45\% more citric acid 6 days earlier than thetreated (Table 4 ). 


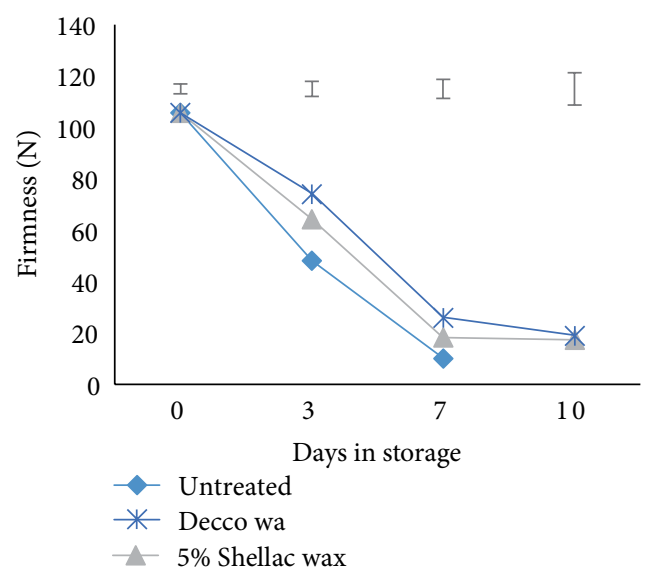

(a)

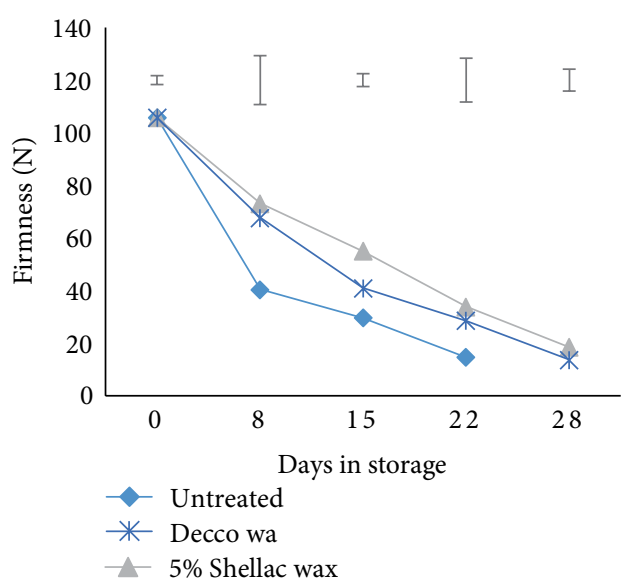

(b)

FIGURE 3: Changes in Peel firmness (N) for "ngowe" mango fruits which were treated with either 5\% Shellac wax, Decco wax or left Untreated (Control) and stored at ambient room temperature, $25^{\circ} \mathrm{C}$ (a) or cold room, $12^{\circ} \mathrm{C}$, (b) top bars represent least significant difference (LSD) of means $(p=0.05)$.

TABLE 1: Changes in Pulp color $\left(\mathrm{H}^{\circ}\right)$ for "ngowe" mango fruits which were treated with either $5 \%$ Shellac wax, Mango Decco wax or left Untreated (Control) and stored in cold storage $\left(12^{\circ} \mathrm{C}\right)$.

\begin{tabular}{lccccc}
\hline \multirow{2}{*}{ Treatment } & \multicolumn{5}{c}{ Days in storage } \\
& 0 & 8 & 15 & 22 & 28 \\
\hline Untreated & $92.51 \mathrm{a}$ & $83.7 \mathrm{a}$ & $81.69 \mathrm{a}$ & $78.39 \mathrm{a}$ & \\
5\% Shellac wax & $92.51 \mathrm{a}$ & $84.86 \mathrm{a}$ & $85.55 \mathrm{a}$ & $84.48 \mathrm{~b}$ & $80.6 \mathrm{a}$ \\
Decco wax & $92.51 \mathrm{a}$ & $83.48 \mathrm{a}$ & $83.9 \mathrm{a}$ & $81.68 \mathrm{~b}$ & $81.66 \mathrm{a}$ \\
\hline Mean & 92.51 & 84.01 & 83.75 & 81.98 & 82.27 \\
LSDs & 1.093 & 4.264 & 4.626 & 1.878 & 3.329 \\
\hline
\end{tabular}

Means within each column followed by different letter differ significantly at $(p<0.05)$.

TABle 2: Changes in Pulp color $\left(\mathrm{H}^{\circ}\right)$ for "ngowe" mango fruits which were treated with either $5 \%$ Shellac wax, Mango Decco wax or left Untreated (Control) and stored at ambient $\left(25^{\circ} \mathrm{C}\right)$.

\begin{tabular}{lcccc}
\hline \multirow{2}{*}{ Treatment } & \multicolumn{5}{c}{ Days in storage } \\
& 0 & 3 & 7 & 10 \\
\hline Untreated & $115.42 \mathrm{a}$ & $81.8 \mathrm{a}$ & $76.38 \mathrm{a}$ \\
5\% Shellac wax & $115.42 \mathrm{a}$ & $89.3 \mathrm{~b}$ & $80.78 \mathrm{~b}$ & $81.05 \mathrm{a}$ \\
Decco wax & $115.42 \mathrm{a}$ & $85.8 \mathrm{~b}$ & $81.19 \mathrm{~b}$ & $82.57 \mathrm{a}$ \\
\hline Mean & 115.42 & 85.63 & 79.45 & 81.81 \\
LSDs & 2.196 & 3.543 & 2.844 & 4.92 \\
\hline
\end{tabular}

Means within each column followed by different letter differ significantly at $(p<0.05)$.

3.6. Changes in Total Soluble Solids (TSS). An increase in TSS was observed in fruits in both storage conditions, but the rate was slower in cold storage compared to ambient storage (Tables 5 and 6). A combination of cold storage and waxing significantly $(p<0.05)$ slowed TSS increase in both storage conditions. In ambient, "ngowe" mango fruits TSS level increased from an initial $10.5^{\circ}$ brix to $20.3^{\circ}$ brix for
TABle 3: Changes in Total Titratable acidity (\% citric acid) for "ngowe" mango fruits which were treated with either 5\% Shellac wax or Decco wax, left Untreated (Control) and stored in cold storage $\left(12^{\circ} \mathrm{C}\right)$.

\begin{tabular}{lcccc}
\hline \multicolumn{1}{c}{ Treatment } & \multicolumn{5}{c}{ Days in storage } \\
& 0 & 3 & 7 & 10 \\
\hline Untreated & $0.755 \mathrm{a}$ & $0.378 \mathrm{a}$ & $0.103 \mathrm{a}$ \\
5\% Shellac wax & $0.755 \mathrm{a}$ & $1.15 \mathrm{~b}$ & $0.18 \mathrm{a}$ & $0.288 \mathrm{a}$ \\
Decco wax & $0.755 \mathrm{a}$ & $1.133 \mathrm{c}$ & $0.467 \mathrm{~b}$ & $0.274 \mathrm{a}$ \\
\hline Means & 0.755 & 0.887 & 0.25 & 0.281 \\
LSDs & 0.265 & 0.230 & 0.112 & 0.081 \\
\hline
\end{tabular}

Means within each column followed by different letter differ significantly at $(p<0.05)$.

TABle 4: Changes in Total Titratable acidity (\% citric acid) for "ngowe" mango fruits which were treated with either 5\% Shellac wax, Decco wax or left Untreated (Control) and stored in cold storage $\left(12^{\circ} \mathrm{C}\right)$.

\begin{tabular}{lccccc}
\hline \multirow{2}{*}{ Treatment } & \multicolumn{5}{c}{ Days in storage } \\
& 0 & 8 & 15 & 22 & 28 \\
\hline Untreated & $0.755 \mathrm{a}$ & $0.352 \mathrm{a}$ & $0.395 \mathrm{a}$ & $0.205 \mathrm{a}$ & \\
5\% Shellac wax & $0.755 \mathrm{a}$ & $0.778 \mathrm{~b}$ & $0.66 \mathrm{~b}$ & $0.404 \mathrm{~b}$ & $0.244 \mathrm{a}$ \\
Decco wax & $0.755 \mathrm{a}$ & $0.667 \mathrm{~b}$ & $0.533 \mathrm{c}$ & $0.364 \mathrm{~b}$ & $0.222 \mathrm{a}$ \\
\hline Means & 0.742 & 0.599 & 0.531 & 0.324 & 0.233 \\
LSDs & 0.2529 & 0.106 & 0.065 & 0.118 & 0.049 \\
\hline
\end{tabular}

Means within each column followed by different letter differ significantly at $(p<0.05)$.

untreated fruits by day 7 compared to a low level of $18.5^{\circ}$ brix and $19.4^{\circ}$ brix for $5 \%$ Shellac wax and Decco wax, respectively, which occurred 3 days later (Table 5). TSS for the cold stored "ngowe" mango fruits increased to a high level of $21.7^{\circ} \mathrm{brix}$ (day 15) compared to the treated whose TSS levels increased to $19.55^{\circ}$ brix (day 15 ) and $19.05^{\circ}$ brix (day 22 ) for $5 \%$ Shellac 
TABLE 5: Changes in total soluble solids ( ${ }^{\circ}$ Brix) for "ngowe" mango fruits which were treated with either $5 \%$ Shellac wax, Decco wax or left Untreated (Control) and stored in ambient $\left(25^{\circ} \mathrm{C}\right)$.

\begin{tabular}{lcccc}
\hline \multirow{1}{*}{ Treatment } & \multicolumn{4}{c}{ Days in storage } \\
& 0 & 3 & 7 & 10 \\
\hline Untreated & $10.5 \mathrm{a}$ & $15.97 \mathrm{a}$ & $20.03 \mathrm{a}$ \\
5\% Shellac wax & $10.5 \mathrm{a}$ & $13.43 \mathrm{~b}$ & $18.85 \mathrm{a}$ & $18.5 \mathrm{a}$ \\
Decco wax & $10.5 \mathrm{a}$ & $14.55 \mathrm{~b}$ & $19.15 \mathrm{a}$ & $19.4 \mathrm{a}$ \\
\hline Mean & 10.5 & 14.65 & 19.34 & 18.95 \\
LSDs & 1.427 & 1.647 & 1.889 & 3.258 \\
\hline
\end{tabular}

Means within each column followed by different letter differ significantly at $(p<0.05)$.

wax and Decco wax, respectively (Table 6). Decco wax was effective in maintaining high TSS level throughout storage (Tables 5 and 6).

3.7. Changes in $\beta$-carotene Content. There was a gradual increase in $\beta$-carotene content as ripening progressed in all fruits, but the rate was slower in cold stored fruits compared to ambient stored fruits (Figures 4(a) and 4(b)). A combination of waxing and cold storage further delayed $\beta$-carotene content development in the different storage conditions. $\beta$-carotene levels for the untreated ambient stored "ngowe" mango fruits increased rapidly from an initial $3.31 \mu \mathrm{g} / 100 \mathrm{~mL}$ to a high level of $5.30 \mu \mathrm{g} / 100 \mathrm{~mL}$ by day 7 compared to a low average of $5.0 \mu \mathrm{g} / 100 \mathrm{~mL}$ for the treated fruits which occurred 3 days later (Figure 4(a)). The trend was similar for cold stored "ngowe" mango fruits as the untreated fruit's $\beta$-carotene content increased to a high of $11.09 \mu \mathrm{g} / 100 \mathrm{~mL}$ (day 22) compared to a low average level of $6.50 \mu \mathrm{g} / 100 \mathrm{~mL}$ (day 28) for the treated fruits (Figure 4(b)).

\section{Discussion}

4.1. Physical and Physiological Changes. Storage temperature is one of the most important factors that influences the deteriorative rate of harvested produce. For every $10^{\circ} \mathrm{C}$ increase in temperature, the rate of deterioration of most perishable commodities increases two to three-fold. The rate of respiration of harvested commodities increases with increase in temperature, thus contributing to a quicker senescence. Relative humidity (moisture content of the atmosphere, expressed as a percentage) is retained depending on temperature and vapor pressure deficit. Increase in temperature causes an increase in the capacity of the air to hold moisture and this affects the rate at which water is lost from stored produce to the environment. Cuticle, a natural waxy layer that prevents water loss and gaseous exchange on the surface of produce is often lost during handling operations. Artificial waxing helps to reinforce the natural wax or replace in cases where most of the cuticle has been removed. Waxing limits the amount of water leaving the produce through transpiration by reducing the number and sizes of the lenticels, thus leading to a water saturated internal environment and also regulates gaseous exchange on the surface of the fruit leading to a high $\mathrm{CO}_{2}$ and low $\mathrm{O}_{2}$ level inside the fruit [15]. The
TABLE 6: Changes in total soluble solids ( ${ }^{\circ}$ Brix) for "ngowe" mango fruits which were treated with either $5 \%$ Shellac wax, Decco wax or left Untreated (Control) and stored in cold storage $\left(12^{\circ} \mathrm{C}\right)$.

\begin{tabular}{lccccc}
\hline \multirow{1}{*}{ Treatment } & \multicolumn{5}{c}{ Days in storage } \\
& 0 & 8 & 15 & 22 & 28 \\
\hline Untreated & $10.5 \mathrm{a}$ & $18.37 \mathrm{a}$ & $21.43 \mathrm{a}$ & $16.54 \mathrm{a}$ & \\
5\% Shellac wax & $10.5 \mathrm{a}$ & $16.5 \mathrm{a}$ & $19.55 \mathrm{~b}$ & $15.9 \mathrm{a}$ & $17.2 \mathrm{a}$ \\
Decco wax & $10.5 \mathrm{a}$ & $15.65 \mathrm{a}$ & $15.45 \mathrm{c}$ & $16.13 \mathrm{a}$ & $22.2 \mathrm{~b}$ \\
\hline Mean & 10.5 & 16.84 & 18.81 & 16.19 & 19.7 \\
LSDs & 1.427 & 2.866 & 2.055 & 2.984 & 3.082 \\
\hline
\end{tabular}

Means within each column followed by different letter differ significantly at $(p<0.05)$.

low oxygen conditions created by waxing affects physiological processes such as respiration and enzyme mediated processes such as the ethylene biosynthesis pathway.

4.1.1. Cumulative Weight Loss (\%). Normally, water is lost by diffusion through the skin to the atmosphere. Previous studies [21] have indicated that this is dependent on relative humidity, temperature, air movement and atmospheric pressure. In the current study, although all fruits gradually lost weight over time, the loss was more drastic in the untreated fruits. Cold stored fruits had lower water loss compared to ambient stored fruits which could be attributed to low temperature that resulted in high humidity and also reduced enzymatic activity involved in breakdown of food reserves. Wax treated fruits were observed to have lower water loss which could be attributed to reduced number and size of lenticels and also reduced respiration rate due to limited gaseous exchange on the surface of fruits that would otherwise lead to production and loss of metabolic water [21]. The effect of coating on reduced weight loss has also been reported in other fruits such as and mango [22].

4.1.2. Changes in Respiration. Reduced respiration rate is an indicator of low metabolic response due to low temperature and $\mathrm{O}_{2}$ level. Fruits stored in ambient $\left(25^{\circ} \mathrm{C}\right)$ exhibited higher respiration compared to those in cold storage $\left(12^{\circ} \mathrm{C}\right)$. For every $10^{\circ} \mathrm{C}$ increase in temperature, the rate of deterioration of most perishable commodities increases two to three-fold. An increased rate in the rate of metabolism has been shown to result into quick deterioration of climacteric fruits such as mango $[23,24]$. Waxing with either Decco wax or Shellac wax provided a protective covering on the fruit peel which provided a semi permeable membrane that acted as gas $\left(\mathrm{CO}_{2}\right.$ and $\mathrm{O}_{2}$ ) barrier, therefore reducing the rate of respiration [12, 25]. Results in the current study concurs with previous studies, where edible films reduced respiration rate in mango fruit resulting in an extended shelf life $[26,27]$.

4.1.3. Changes in Pulp Color. Color change from green to orange is attributed to the loss of chlorophyll and appearance of other pigments [28]. In the present study, pulp hue angle decreased progressively with ripening in all fruits irrespective of treatment and storage. Cold stored fruits retained higher peel color $\left(97.26^{\circ}\right)$ compared to ambient stored fruits $\left(87.12^{\circ}\right)$. Further, waxing delayed the rate of chlorophyll breakdown compared to 


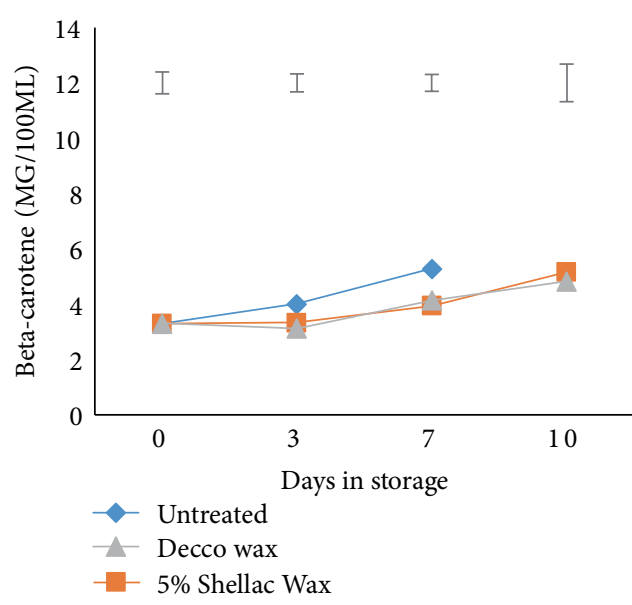

(a)

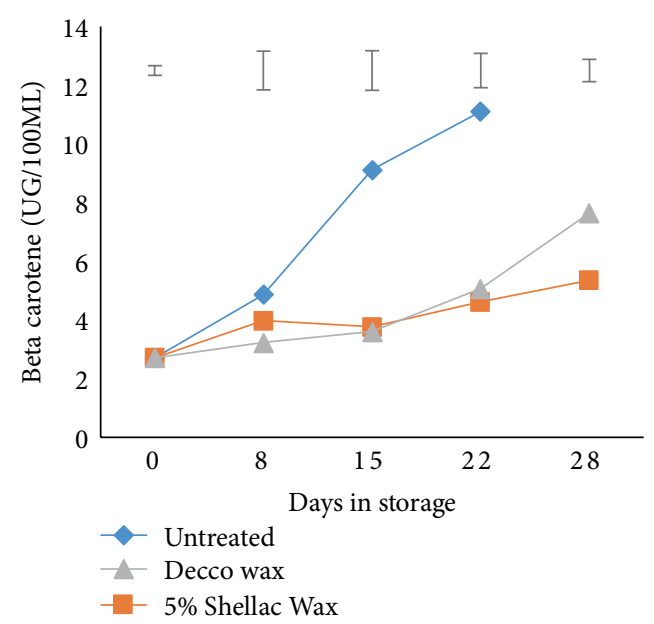

(b)

Figure 4: Changes in Beta carotene $(\mu \mathrm{g} / 100 \mathrm{~mL})$ "ngowe" mango fruits which were treated with either $5 \%$ Shellac wax, Decco wax or left Untreated (Control) and stored at ambient room temperature, $25^{\circ} \mathrm{C}(\mathrm{a})$ or cold room, $12^{\circ} \mathrm{C}$, (b) top bars represent least significant difference (LSD) of means $(p=0.05)$.

untreated which can be attributed to reduced enzyme activity due to modified conditions of low $\mathrm{O}_{2}$ and high $\mathrm{CO}_{2}$ levels inside the coated fruits. The results from this study are similar to those reported on studies of other mango varieties [29, 30].

4.1.4. Changes in Firmness. Decrease in firmness during ripening is associated with activities of the enzymes involved in cell wall metabolism including pectin methylesterase (PME), polygalacturonase (PG), endo-B-1,4- glucanase (EGase) and pectatelyase activities [17]. The delayed loss in firmness in the waxed fruits especially for the cold stored fruits, could be attributed to reduced enzyme activity due to low temperature and modified conditions of low $\mathrm{O}_{2}$ and high $\mathrm{CO}_{2}$ created by the coating, thus retaining membrane integrity longer. The study confirms other results reported on the effect of coating on mango (Choke anan variety), whereby chitosan treated fruits retained high firmness $(45 \mathrm{~N})$ compared to untreated fruit's low firmness $(20 \mathrm{~N})$ by end of storage period (day 28) [15].

\subsection{Changes in Postharvest Quality}

4.2.1. Changes in Total Soluble Solids. Increase in total soluble solids (TSS) during ripening is associated with the breakdown of stored carbohydrates to yield respiratory substrates necessary for maintaining the metabolic activities [31]. In both storage conditions, TSS increased gradually for all fruits as ripening progressed, but the rate was relatively low each sampling day for the cold stored $\left(12^{\circ} \mathrm{C}\right)$ fruits compared to ambient stored $\left(25^{\circ} \mathrm{C}\right)$ fruits which could be attributed to reduced enzymatic activities due to low temperature. Further, the cold stored waxed fruits had low TSS levels (19.7 $\left.{ }^{\circ} \mathrm{brix}\right)$ by day 28 compared to the untreated fruit's high TSS levels ( $21.43^{\circ}$ brix) by day 15 , which could be attributed to low $\mathrm{O}_{2}$ and high $\mathrm{CO}_{2}$ concentration inside the fruits as created by the coating. Related results have been reported on the effect of Chitosan on cold-stored mango where the untreated had high brix ( $22^{\circ}$ brix) compared to low brix ( $11^{\circ}$ brix) for the treated by end of storage period (day 28) [23].
4.2.2. Changes in Total Titratable Acidity. Untreated fruits total titratable acidity reduced faster compared to Decco and shellac wax treated fruits. This could be due to the utilization of the acid as a respiratory product during ripening [26], while the two coatings helped in maintaining TTA contents, an indicator that the coatings could delay the use of organic acid as a respiratory product. TTA reduction was slower in cold stored fruits compared to the ambient stored fruits which could be attributed to reduced enzymatic activity due to low temperature.

4.2.3. Changes in Beta Carotene Content. The change in color of the mango pulp (cream to yellow/orange) is attributed to accumulation of beta carotene. In the current study, beta carotene content increased with storage time and as the fruits ripened but the increase was gradual for cold stored fruits compared to ambient stored, which could be attributed to reduced enzymatic activities due to low temperature. Beta carotene content development for the waxed fruits in both storage conditions was delayed compared to untreated fruits probably due to delayed synthesis and accumulation of beta carotene as a result of low $\mathrm{O}_{2}$ and high $\mathrm{CO}_{2}$, which interfered with the enzymes involved in the synthesis or unmasking of preexisting color pigments [32,33].

\section{Conclusion}

The findings from this study show that Decco wax and Shellac wax can delay mango fruit ripening and therefore extend the shelf life and consequently the marketing period for the fruits. Waxing coupled with cold storage resulted in more than two times the storage period for mangoes under ambient storage. This implies that cold storage is important to realize the potential benefits of waxing to preserve quality and extend the shelf life of mango fruit. 


\section{Data Availability}

The data used in the development of this manuscript are available upon request, by reaching out to, mainabenson866@ gmail.com.

\section{Conflicts of Interest}

The authors declare that there are no conflicts of interest.

\section{Funding}

The mango wax and supportive funding for this research was provided by UPL Limited and the Rockefeller Foundation under the YieldWise Initiative.

\section{References}

[1] M. Lauricella, S. Emanuele, G. Calvaruso, M. Giuliano, and A. D'Anneo, "Multifaceted health benefits of Mangifera indica L. (mango): the inestimable value of orchards recently planted in Sicilian rural areas," Nutrients, vol. 9, p. 525, 2017.

[2] A. Carrillo-Lopez, F. Ramirez-Bustamante, J. B. Valdez-Torres, R. Rojas-Villegas, and E. M. Yahia, "Ripening and quality changes in mango fruit as affected by coating with an edible film," Journal Food Quality, vol. 23, pp. 479-486, 2000.

[3] D. C. Slaughter, "“'Non-destructive maturity assessment methods for mango". A review of Literature and identification of future," Research Needs, 2009.

[4] S. Srivastava, R. K. Singh, G. Pathak et al., "Comparative transcriptome analysis of unripe and mid-ripe fruit of Mangifera indica (var. 'Dashehari') unravels ripening associated genes," Scientific Reports, vol. 6, Article ID 32557, 2016.

[5] K. M. Maguire, N. H. Banks, and L. U. Opara, "Factors affecting weight loss of apples," Horticultural Reviews, vol. 25, pp. 197234, 2001.

[6] X. Zheng, L. Ye, T. Jiang, G Jing, and J Li, "Limiting the deterioration of mango fruit during storage at room temperature by oxalate treatment," Food Chemistry, vol. 130, no. 2, pp. 279$285,2012$.

[7] M. D. Meyer, S. Landahl, M. Donetti, and L. A. Terry, Avocado In Health-promoting properties of fruit and vegetables, $\mathrm{CAB}$ International, Oxford, UK, pp. 27-50, 2011.

[8] R. W. Githiga, "Effect of 1-Methylcyclopropene and activebag packaging on the postharvest characteristics of mango fruit (Mangifera indica L) cultivar tommy atkins Master of Science Thesis," University of Nairobi, Kenya, 2012.

[9] E. A. Baldwin, in Edible Coatings for Fresh Fruits and Vegetables: Past, Present, and Future. In Edible Coating and Films to Improve Food QualityTechnomic, J. M. Krochta, E. A. Baldwin, and M. O. Nisperos Carriedo, Eds., pp. 25-64, Publishing Co, Lancaster, PA, 1994.

[10] A. K. Thompson, Fruits and Vegetables Harvesting, Handling and Storage, Blackwell Publishers Limited, 2003.

[11] S. Nair and Z. Singh, "Pre-storage ethrel dip reduces chilling injury, enhances respiration rate, ethylene production and improves fruit quality of 'Kensington Pride' mango," Journal of Food, Agriculture and Environment, vol. 1, no. 2, pp. 93-97, 2003.

[12] E. Baldwin, W. Burns, J. K. Kazokas, R. D. Brecht, R. J. Hagenmaier, and E. Pesis Bender, "Effect of two coatings with different permeability characteristics on mango (Mangifera indica L.) ripening during storage," Postharvest Biology and Technology, vol. 17, pp. 215-226, 1999.

[13] A. Ali, M. Maqbool, S. Ramachandran, and P. G. Alderson, "Gum arabic as a novel edible coating for enhancing shelflife and improving postharvest quality of tomato (Solanum lycopersicum L.) fruit," Postharvest Biology and Technology, vol. 58, no. 1, pp. 42-47, 2010.

[14] T. T. Hoa, M.-N. Ducamp, M. Lebrun, and E. A. Baldwin, "Effect of different coating treatments on the quality of mango fruit," Journal of Food Quality, vol. 25, no. 6, pp. 471-486, 2002.

[15] R. D. Hagenmaier and R. A. Baker, "Wax micro emulsions and emulsions as citrus coatings," Journal of Agricultural and Food Chemistry, vol. 42, no. 4, pp. 899-902, 1994.

[16] P. J. Hofman, L. G. Smith, R. Holmes, T. Campbell, and G. Meiburg, "Mango fruit quality at harvest is affected by production conditions," in Proceedings of Mango 2000 marketing seminar and production workshop Brisbane, Australia, pp. 199208, 1994.

[17] E. Persis, M. Eckerman, R. Ben-Arie et al., "Ethylene involvement in chilling injury symptoms of avocado during cold storage," Postharvest Biology and Technology, vol. 24, pp. 171-181, 2002.

[18] G. Cheng, X. Duan, Y. Jiang et al., "Modification of hemicellulose polysaccharides during ripening of postharvest banana fruit," Food Chemistry, vol. 115, no. 1, pp. 43-47, 2009.

[19] K. Omry, "Postharvest manager, amiran Kenya limited. personal," Communication, 2011.

[20] R. K. Dhall, "Advances in edible coatings for fresh fruits and vegetables: a review," Critical Reviews in Food Science and Nutrition, vol. 53, no. 5, pp. 435-450, 2013.

[21] H. A. Rathore, T. Masud, S. Sammi, and H. A. Soomro, "Effects of storage on physico-chemical composition and sensory properties of mango (Mangifera indica L.) var. Dosehari," Pakistan Journal of Nutrition, vol. 6, no. 2, pp. 143-148, 2007.

[22] B. G. de S. Medeiros, A. C. Pinheiro, M. G. Carneiro-daCunha, and A. A. Vicente, "Development and characterization of a nanomultilayer coating of pectin and chitosan evaluation of its gas barrier properties and application on 'Tommy Atkins' mangoes," Journal of Food Engineering, vol. 110, no. 3, pp. 457-464, 2012.

[23] H. J. Park, "Development of advanced edible coatings for fruits," Trends in Food Science \& Technology, vol. 10, no. 8, pp. 254-260, 1999.

[24] P. E. Zerbini, M. Vanoli, A. Rizzolo et al., "Optical properties, ethylene production and softening in mango fruit," Postharvest Biology and Technology, vol. 101, pp. 58-65, 2015.

[25] G. Khaliq, M. T. M. Mohamed, A. Ali, P. Ding, and H. M. Ghazali, "Effect of gum arabic coating combined with calcium chloride on physico-chemical and qualitative properties of mango (Mangifera indica L.) fruit during low temperature storage," Scientia Horticulturae, vol. 190, pp. 187-194, 2015.

[26] F. Kittur, N. Saroja, Habibunnisa, and R. Tharanathan, "Polysaccharide-based composite coating formulations for shelf-extension of fresh banana and mango," European Food Research and Technology, vol. 213, no. 4, pp. 306-311, 2010. 
[27] M. Moalemiyan, H. S. Ramaswamy, and N. Maftoonazad, "Pectin-based edible coating for shelf-life extension of Ataulfo mango," Journal of Food Process Engineering, vol. 35, no. 4, pp. 572-600, 2012.

[28] A. P. Medlicott, M. Bhogol, and S. B. Reynolds, "Changes in peel pigmentation during ripening of mango fruit Mangifera indica var. 'Tommy Atkins,' Annals of Applied Biology, vol. 109, no. 3, pp. 651-656, 1986.

[29] I. P. Ibarra-Garza, P. A. Ramos-Parra, C. Hernández-Brenes, and D. A. Jacobo-Velázquez, "Effects of postharvest ripening on the nutraceutical and physicochemical properties of mango (Mangifera indica L. cv 'Keitt')," Postharvest Biology and Technology, vol. 103, pp. 45-54, 2015.

[30] H. Palafox-Carlos, E. M. Yahia, M. Islas-Osuna, P. GutierrezMartinez, M. Robles-Sánchez, and G. González-Aguilar, "Effect of ripeness stage of mango fruit (Mangifera indica L., cv. 'Ataulfo') on physiological parameters and antioxidant activity," Scientia Horticulturae, vol. 135, pp. 7-13, 2012.

[31] S. Saranwong, J. Sornsrivichai, and S. Kawano, "Performance of a portable NIR instrument for Brix value determination of intact mango fruit," Journal of Near Infrared Spectroscopy, vol. 11, no. 3, pp. 175-181, 2003.

[32] F. M. Mathooko, "A comparison of modified atmosphere packaging under ambient conditions and low temperature storage on quality of tomato fruit," African Journal of Food, Agriculture, Nutrition and Development, vol. 3, no. 2, pp. 2-9, 2004.

[33] B. Jarimopas and U. Kitthawee, "Firmness properties of mangoes," International Journal of Food Properties, vol. 10, no. 4, pp. 899-909, 2007. 


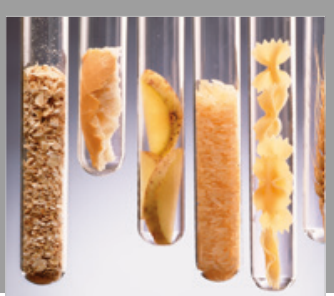

International Journal of Food Science

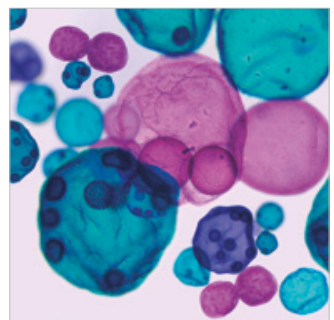

International Journal of Microbiology
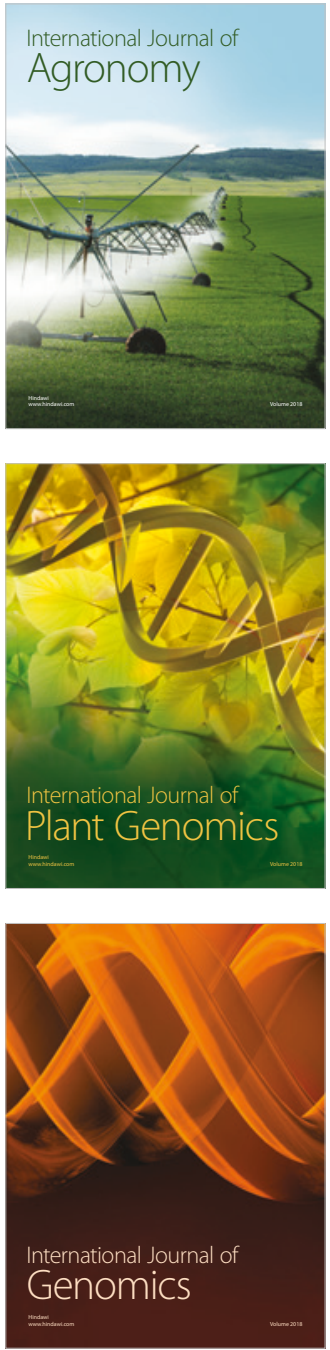

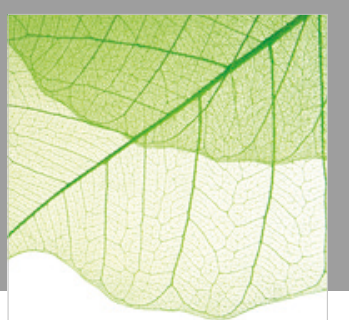

Journal of Botany
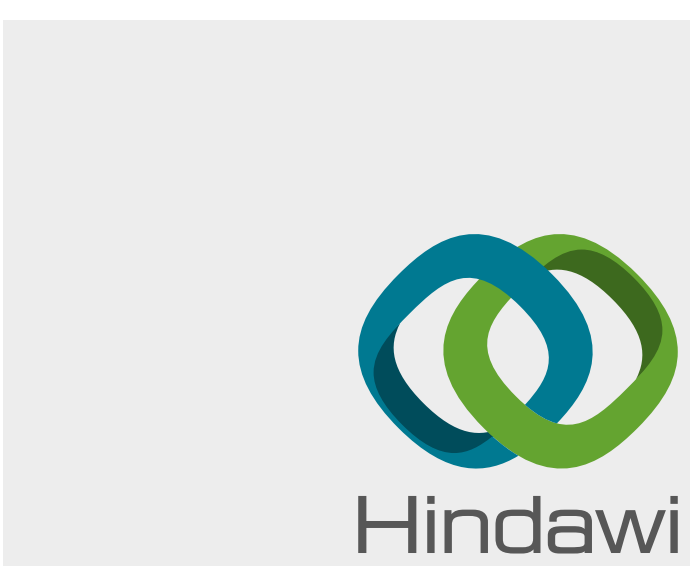

Submit your manuscripts at

www.hindawi.com
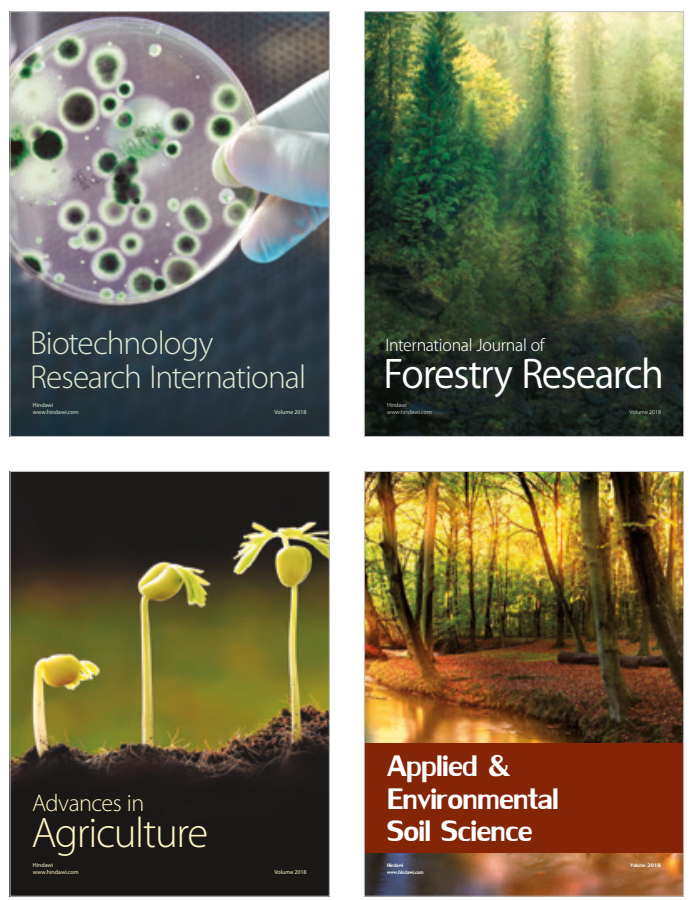

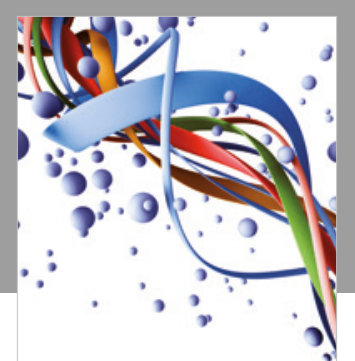

Scientifica

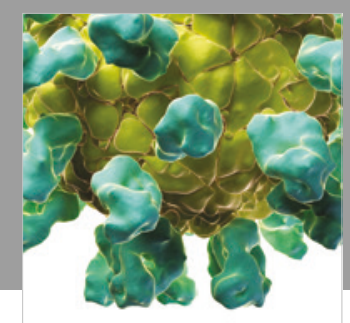

Veterinary Medicine International

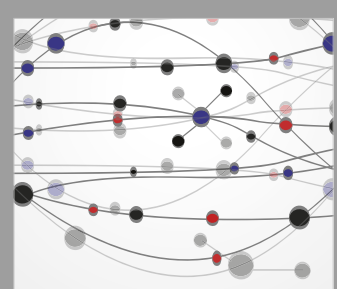

The Scientific World Journal
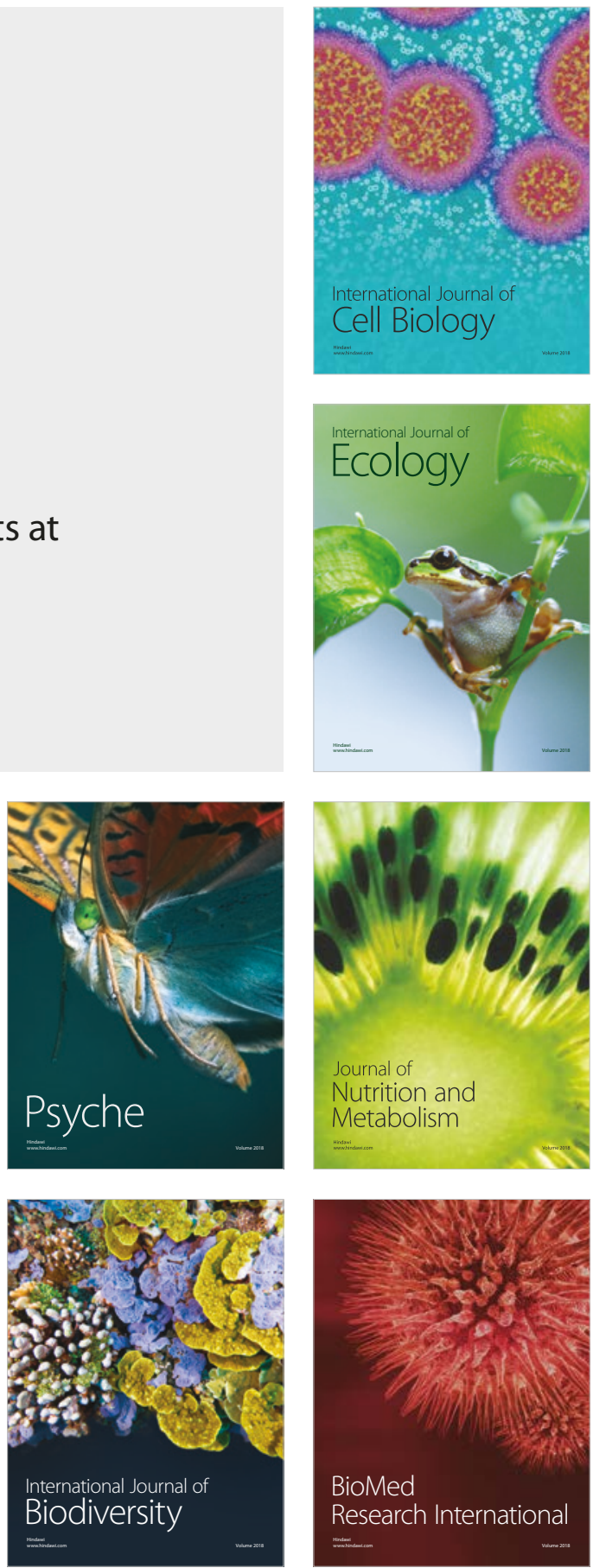